\title{
Morphology of the epaxial musculature and osteological development of the early developmental stages of softmouth trout (Salmothymus obtusirostris, Heckel, 1851)
}

\section{Srebrenka Nejedli ${ }^{1 *}$, Zvonimir Kozarić ${ }^{1}$, Ivan Katavić², Ivona Žura Žaja ${ }^{3}$, and Ivana Tlak Gajger ${ }^{4}$}

\author{
${ }^{I}$ Department of Anatomy, Histology and Embryology, Faculty of Veterinary Medicine, University of Zagreb, \\ Zagreb, Croatia \\ ${ }^{2}$ Institute of Oceanography and Fisheries, Split, Croatia \\ ${ }^{3}$ Department of Physiology and Radiobiology, Faculty of Veterinary Medicine, University of Zagreb, Zagreb, \\ Croatia \\ ${ }^{4}$ Department of Biology and Pathology of Fish and Bees, Faculty of Veterinary Medicine, University of \\ Zagreb, Zagreb, Croatia
}

\section{NEJEDLI, S., Z. KOZARIĆ, I. KATAVIĆ, I. ŽURA ŽAJA, I. TLAK GAJGER: Morphology of the epaxial musculature and osteological development of the early developmental stages of softmouth trout (Salmothymus obtusirostris, Heckel, 1851). Vet. arhiv 88, 89-100, 2018.}

\section{ABSTRACT}

Investigations were carried out on the early developmental stages of softmouth trout (Salmothymus obtusirostris, Heckel, 1851), taken from a hatchery in Proložac near the River Vrljika, Croatia. Samples were collected every two days 10-56 days post-hatching (dph), fixed in 10\% buffered formalin, embedded in paraffin, cut into $10 \mu \mathrm{m}$ thick serial longitudinal sections and stained with Hematoxylin and Eosin, Toluidin Blue, Alcian Blue-specific $(\mathrm{pH}=2.5)$ and Alcian Blue and Alizarin Red. The number of myomeres in the dorsal epaxial musculature of the softmouth trout increased between 10-18 dph and 50-56 dph to either 42 or 59 myomeres, respectively. Total body length increased from a minimal value of $19.57 \mathrm{~mm}$ to a maximum value of $25.80 \mathrm{~mm}$ between 10-56 dph. The number of vertebrae in all investigated groups was 59. Through this follow-up of the period of development of softmouth trout to the stage of complete yolk sac absorption it was established that it takes about 24 to $26 \mathrm{dph}$ when they start opening their mouth and when all the bones of the head and all fins are visible. In the period of 26-56 dph the number of myomeres was 55-59, and this could be used for taxonomic identification of the early developmental stages of softmouth trout. Throughout whole investigation period no signs of ossification in the vertebral column, fins and head bones were observed or any skeletal malformations.

Key words: softmouth trout; Salmothymus obtusirostris, Heckel, 1851; early developmental stages; epaxial muscles; osteological development

\footnotetext{
*Corresponding author:

Srebrenka Nejedli, DVM, Department of Anatomy, Histology and Embryology, Faculty of Veterinary Medicine, University of Zagreb, Heinzelova 55, 10000 Zagreb, Croatia, Phone: + 38512390 242; E-mail: snejedli@vef.hr
} 
S. Nejedli et al.: Morphology of epaxial musculature and osteological development of softmouth trout

\section{Introduction}

The softmouth trout (S. obtusirosis) is an endemic species of the Adriatic Basin (ĆALETA et al., 2015) assigned to the family of salmonids on the Balkan peninsula KOTTELAT and FREYHOF (2007). Its natural distribution is limited to a few Adriatic rivers in Croatia, Bosnia and Herzegovina and Montenegro. There are five natural populations of this subspecies, found in the rivers Neretva, Vrljika, Jadro, Krka and its confluents, and the Zeta (ĆALETA et al., 2015). It has been noted that the softmouth trout was previously considered as a separate genus of Salmothymus, and its populations in different rivers and their confluents sometimes have different subspecies (ROGLIĆ, 2012).

The River Vrljika has rich biological diversity and endemic species of freshwater fish, including $S$. obtusirostris, which are the only salmonid known to inhabit this river (SNOJ et al., 2008). The body is spindle-shaped with a short head and the teeth are small or non-existent. The scales on the body of the fish are small, and field of the lateral line is between 100 and 120 (ROGLIĆ, 2012). They have an adipose fin situated behind the dorsal fin, at the beginning of the caudal peduncle, body coloration varies and the $S$. obtusirostris from the River Vrljika is yellowish-green to golden yellow (ĆALETA et al., 2015). Usually, in S. obtusirostris the final development of gonads occurs in the spring, mainly from February to April (ĆALETA et al., 2015).

Aquaculture enables rapid production of good quality fish meat. Growth of farmed fish, especially of the larvae in the developing stages (as is the case in nature) depends on many environmental factors, such as water temperature, the type, amount and composition of feed, the feeding system, etc. (GALLOWAY et al., 1999; AYALA et al., 2001; LOPEZALBORS et al., 2003). Selective breeding programs, as well as advances in understanding of the nutritional requirements, have succeeded in dramatically increasing muscle growth rates in salmonid fish (JOHNSTON, 2001).

A great deal of fish cultured products come from salmonid farms (BOGLIONE et al., 2014) and studies of muscle growth are therefore important for the future development of fish farming. Fish muscles are known to be suitable for study because they are not distinctly separated, as is the case with the muscles of higher vertebrates. In addition, they have less connective tissue and segmented structure. Muscle segments (myomeres) are separated from each other by connective tissue septa (myosepts). The number of myomeres and vertebrae are considered to be a good indication in the taxonomic identification of fish species (ARAÚJO-LIMA and DONALD, 1988; OCHOA et al., 2010). Muscles consist of muscle fibres and some connective tissue. Body and tail muscles support the backbone on the left and right sides, beneath and above the vertebrae, both epaxially and hypaxially. There are separate muscles along the fins and head bones. The major part of the trunk and tail muscles consists of white muscle fibres used for forceful and rapid contractions during hunting of prey or escaping from predators, and they quickly show fatigue (VAN 
LEEUWEN, 1995), in comparison to the red muscles which comprise a markedly smaller portion of the muscles (COUGHLIN, 2002). Skeletal muscles in fish develop hypertrophy and hyperplasia (GALLOWAY et al., 1999). The myomeres are separated by miosepta collagenous sheets with complex fibre patterns (VAN LEEUWEN, 1999) and white muscle comprises more than $90 \%$ of the myomeres in most species (JOHNSTON et al., 2000). Knowledge of the morphological aspects of skeletal development provides valuable information to prevent early incidences of malformations in farmed fishes (ÇOBAN et al., 2009).

Some species such as S. obtusirostris are endemic and threatened, and therefore controlled production is important to repopulate their natural habitat (TOMLJANOVIĆ, 2014). Since studies on the $S$. obtusirostris are lacking, we investigated the number of myomeres in the epaxial musculature, vertebral quantification and ossification of bones as well as the opening of the mouth of S. obtusirostris.

\section{Materials and methods}

Investigations were carried out on one hundred softmouth trout in early developmental stages ( $S$. obtusirostris) at age 10-56 days post-hatching (dph) taken from a pilot scale hatchery located in Proložac near the River Vrljika in Croatia, as part of the restocking programme of the River Vrljika. Spawning and incubation were carried out at environmental temperature, which ranged from $10-11{ }^{\circ} \mathrm{C}$ corresponding to the River Vrljika environment. Fish were first fed with Artemia salina and later with commercial starter feed (EWOS micro crumble feeds). Fish were sampled every two days from 10-56 dph and fixed in 10\% buffered formalin. Juvenile fish were embedded in paraffin and cut longitudinally in series sections of $10 \mu \mathrm{m}$ in thickness and were stained with Hematoxylin and Eosin (HE) (ROMEIS, 1968), Toluidin Blue specific staining (PEARSE, 1968) Alcian Blue-specific ( $\mathrm{pH}=2.5)(\mathrm{MOWRY}, 1956)$ and Alcian Blue and Alizarin Red (DINGERKUS and UHLER, 1977) staining. The described procedure was applied in order to show the tissue structure (muscles, cartilage and bones), to measure myomeres in the epaxial musculature, to show the possibility of bone ossification, to count the vertebrae and determine the time of the opening of the mouth. The cartilage stained blue when Alcian Blue and Alizarin Red were used, while bone tissue stained red. Total body length (TL) was measured using a Stereomicroscope, Olympus S761 with the use of a microscopic camera, PROMICRA. Basic statistical analyses were obtained using GraphPad Prism software (USA).

\section{Results}

The average number of myomeres increased during the investigated period, and it was between 10-18 dph 42.17, 20-28 dph 50.40, 30-38 dph 55.65, 40-48 dph 56.92, 50-56 
dph 58.90 myomeres, respectively (Table 1). The total body length (TL) increased from the minimal body length of $19.57 \mathrm{~mm}$ between $10-18 \mathrm{dph}$ to the maximum $25.80 \mathrm{~mm}$ between 50-56 dph (Table 1). The number of vertebrae in all investigated groups was 59 .

Table 1. Total body length, number of myomeres and vertebrae of softmouth trout

(S. obtusirostris, Heckel, 1851).

\begin{tabular}{|c|c|c|c|c|}
\hline $\begin{array}{l}\text { Age of softmouth } \\
\text { trout in days }\end{array}$ & $\begin{array}{c}\text { Parameters of } \\
\text { description statistics }\end{array}$ & $\begin{array}{c}\text { Total body } \\
\text { length }(\mathrm{mm})\end{array}$ & $\begin{array}{l}\text { Number of } \\
\text { myomeres }\end{array}$ & $\begin{array}{c}\text { Number of } \\
\text { vertebrae }\end{array}$ \\
\hline \multirow{4}{*}{$\begin{array}{l}10-18 \\
(\mathrm{n}=17) \\
\left(\mathrm{n}^{\prime}=12\right)\end{array}$} & $\mathrm{M}$ & 20.28 & 42.17 & \multirow{3}{*}{59} \\
\hline & Min & 19.57 & 37 & \\
\hline & Max & 20.83 & 47 & \\
\hline & SD & 0.63 & 5.00 & \\
\hline \multirow{4}{*}{$\begin{array}{l}20-28 \\
(\mathrm{n}=22) \\
\left(\mathrm{n}^{\prime}=15\right)\end{array}$} & $\mathrm{M}$ & 21.63 & 50.40 & \multirow{3}{*}{59} \\
\hline & Min & 21.30 & 47 & \\
\hline & Max & 21.89 & 55 & \\
\hline & SD & 0.30 & 4.01 & \\
\hline \multirow{4}{*}{$\begin{array}{l}30-38 \\
(\mathrm{n}=25) \\
\left(\mathrm{n}^{\prime}=20\right)\end{array}$} & $\mathrm{M}$ & 22.38 & 55.65 & \multirow{3}{*}{59} \\
\hline & Min & 22.26 & 55 & \\
\hline & Max & 22.50 & 57 & \\
\hline & SD & 0.12 & 1.02 & \\
\hline \multirow{4}{*}{$\begin{array}{l}40-48 \\
(\mathrm{n}=21) \\
\left(\mathrm{n}^{\prime}=13\right)\end{array}$} & Mean & 23.55 & 56.92 & \multirow{3}{*}{59} \\
\hline & Min & 22.65 & 56 & \\
\hline & Max & 24.15 & 58 & \\
\hline & SD & 0.75 & 1.00 & \\
\hline \multirow{4}{*}{$\begin{array}{l}50-56 \\
(\mathrm{n}=15) \\
\left(\mathrm{n}^{\prime}=10\right)\end{array}$} & Mean & 25.42 & 58.90 & \multirow{3}{*}{59} \\
\hline & Min & 25.07 & 58 & \\
\hline & Max & 25.80 & 59 & \\
\hline & SD & 0.37 & 0.55 & \\
\hline
\end{tabular}

M - mean value, SD - standard deviation, Min - minimum, Max - maximum, $\mathrm{n}$ - number of fish used for body length measurements, $n^{\prime}$ - number of fish used for counted of myomers and vertebrae

At the age of $10 \mathrm{dph}$ the head could be seen in the $S$. obtusirostris (Fig. 1). The eye could be seen with the developing retina at the age of $12 \mathrm{dph}$ (Fig. 2) while retinal layers were completely developed at the age of $18 \mathrm{dph}$ (Fig. 3).

The myomeres counted below the head (Fig. 4), on the trunk (Fig. 5) and tail parts of body (Fig. 6) were clearly visible. The period of larval development to the stage of complete yolk sac absorption took about 24 to $26 \mathrm{dph}$ when they started opening their mouth and all the fins and head bones were formed (Fig. 7). In all examined specimens, no signs of ossification in the spine, fins or head bones were seen, or any skeletal malformations (Fig. 7). 
S. Nejedli et al.: Morphology of epaxial musculature and osteological development of softmouth trout

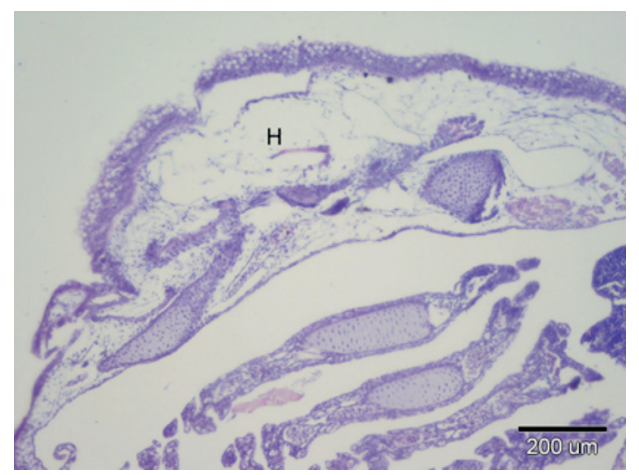

Fig. 1. The head (H) of a softmouth trout (S. obtusirostris, Heckel, 1851) at $10 \mathrm{dph}$, transverse section, $H \& E, \times 10$.

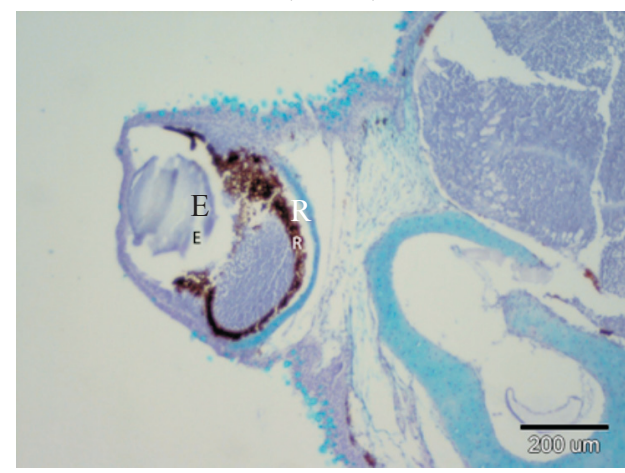

Fig. 2. The eye (E) with developing retina (R) of a softmouth trout (S. obtusirostris, Heckel, 1851) at $12 \mathrm{dph}$, transverse section, Alcian Blue, $\times 10$.

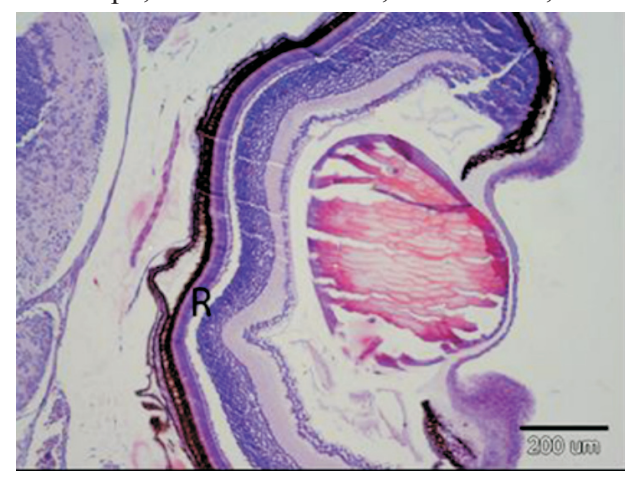

Fig. 3. The eye with completely developed retinal layers (R) of a softmouth trout (S. obtusirostris, Heckel, 1851) at $18 \mathrm{dph}$, transverse section, $\mathrm{H} \& \mathrm{E}, \times 10$.

Vet. arhiv $88(1), 89-100,2018$ 
S. Nejedli et al.: Morphology of epaxial musculature and osteological development of softmouth trout

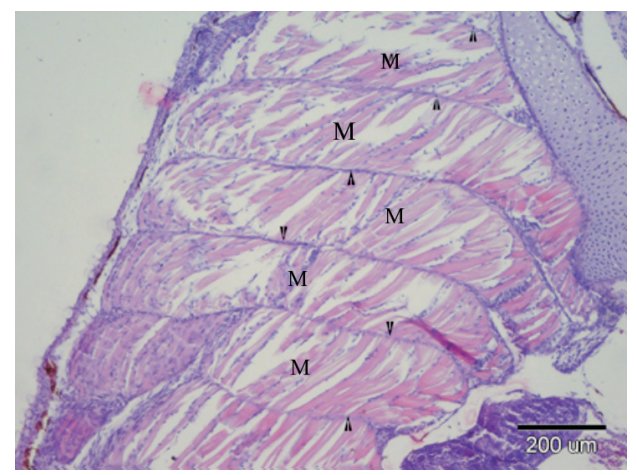

Fig. 4. Myomeres (M) and myosepta (arrowhead) in the epaxial musculature below the head of A softmouth trout (S. obtusirostris, Heckel, 1851) seen at $18 \mathrm{dph}$, transverse section, H\&E, $\times 10$.

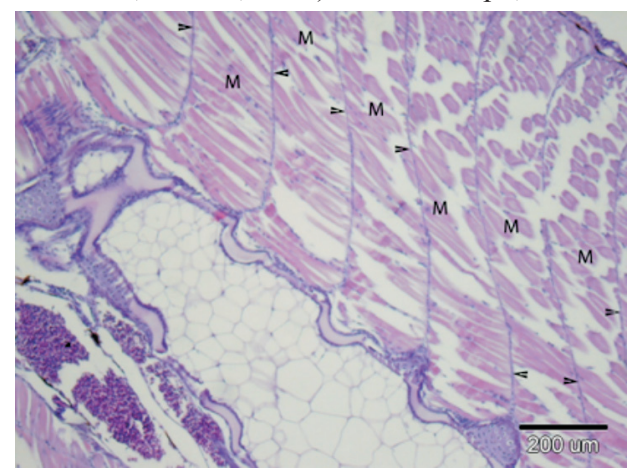

Fig. 5. Myomeres (M) and myosepta (arrowhead) in the epaxial musculature on the trunk of A softmouth trout (S. obtusirostris, Heckel, 1851) seen at 56 dph, transverse section, H\&E, $\times 10$.

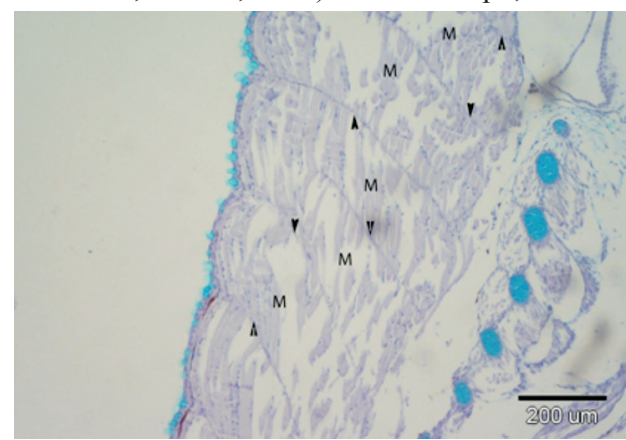

Fig. 6. Myomeres (M) and myosepta (arrowhead) in the epaxial musculature on the tail of A softmouth trout (S. obtusirostris, Heckel, 1851) seen at 18 dph, transverse section, Alcian Blue, $\times 10$. 


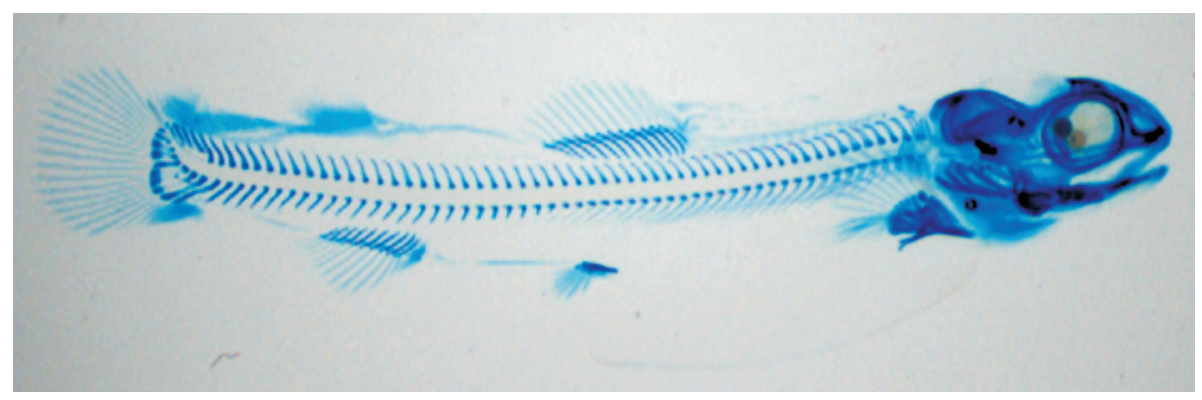

Fig. 7. Skeletal system of the softmouth trout (S. obtusirostris, Heckel, 1851), at $24 \mathrm{dph}$, Alcian Blue and Alizarin Red, $\times 4$.

\section{Discussion}

ĆALETA et al. (2015) described the distribution and reduced habitat of all four subspecies of the S. obtusirostris: the Neretva softmouth trout (S. o. oxyrthynchus), Krka softmouth trout (S. o. krkensis), Solin softmouth trout (S. o. salonitana) and Zeta softmouth trout (S. o. zetensis). In the Red Book of Freshwater Fish in Croatia (MRAKOVČIĆ et al., 2006) Vrljika softmouth trout have been equated with the Jadro softmouth trout, but the genetic results of mitochondrial DNA haplotypes (control region, partial cytochrome $\mathrm{b}$ and ATPase 6 genes) indicate a sister relationship between the Vrljika and Neretva softmouth (Adriatic) trout S. obtusirostris (SNOJ et al., 2008). The Vrljika softmouth trout can be identified by an array of derived phenotypic and molecular character states. Therefore, for the conservation of this population it should be formally recognized at the same taxonomic level as other geographically separated populations of softmouth trout (SNOJ et al., 2008).

Accurate identification of fish species at all stages from larvae to adult is justified, to support the ichthyological studies which provide basic information for management (TERMVIDCHAKORN and HORTLE, 2013). In our investigations, the development of the S. obtusirostris juvenile fish was analysed, primarily the number of myomeres. In fish at the age of 10-56 dph, the average number of myomeres increased and was between 10-18 dph 42.17, 20-28 dph 50.40, 30-38 dph 55.65, 40-48 dph 56.92 and 5056 dph 58.90 myomeres. As compared to our results KANG et al. (2014) also found in Acanthopagrus schlegeli an increasing trend in the number of myomeres from 22 to 26 at TL from 2.04 to $3.24 \mathrm{~mm}$. The number of vertebrae in all investigated groups was 59 . In adult S. obtusirostris ROGLIĆ (2012) determined 53-70 vertebrae. TREMBLAY et al. (1984) found approximately 54 vertebras in the larvae of haddock at TL $8-41 \mathrm{~mm}$ and 45-220 mm. Myomere counts in older specimens are often equivalent to vertebrae counts (TERMVIDCHAKORN and HORTLE, 2013). 
The TL of S. obtusirostris increased from 19.57 to $25.80 \mathrm{~mm}$ between $10-56 \mathrm{dph}$. Considering the fact that the larva's ability to move is related to its size (SPIERTS, 2001), it should be noted that there is also a relationship to feeding (GALLOWAY et al., 1999; COUGHLIN, 2002).

Salmonidae are teleostei and the study of the osteological development is important in fisheries, biology and aquaculture (HASANPOUR et al., 2015). From the fisheries' perspective, it helps in identifying fish in early developmental stages (FRITZSCHE and JOHNSON, 1980; SAKA et al., 2008). The development of osteological structure in teleostei is of crucial value in phylogenetic studies (KOUMONDOUROUS et al., 2001). According to the present study no data about development and ossification processes in the $S$. obtusirostris were obtained. In our investigations of $S$. obtusirostris no signs of ossification were observed in the vertebral column or in the fins or head bones during period of $56 \mathrm{dph}$. A completely ossified vertebral column in Salmo letnica, Karaman, 1924 (Teleostei: Salmonidae) was observed in 92 day-old trout (RISTOVSKA et al., 2006).

Knowledge about the normal development of the skeleton is crucial (HASANPOUR et al., 2015) in addressing when and where abnormalities occur under rearing conditions. It can be used as an early bio-indicator of non-optimal rearing conditions (LEWIS and LALL, 2006) and also as a parameter of a proper diet (CAHU et al., 2003). Fish-like trout cannot swim efficiently with spinal deformities so they have greater risk from predators and are less capable of taking food (SILVESTRONE and HAMMELL, 2002). Farm fish are affected by skeletal malformations with the incidence depending on the species and developmental stage (BOGLIONE et al., 2014). In all investigated S. obtusirostris we did not notice any skeletal malformations. On the other hand, ROGLIĆ (2012) reported that out of the 88 S. obtusirostris, sampled from hatcheries in Proložac, only two $(2.27 \%)$ had deformation of the spine.

The transition from endogenous to exogenous feeding which follows hatching is a critical stage in larval development, and is reflected in the overall degree of muscle development at that time (KOUMANS and AKSTER, 1995). The period of development of $S$. obtusirostris to stage of complete yolk sac absorption when they started opening their mouths was about 24 to $26 \mathrm{dph}$, which is similar to the results obtained by ROGLIĆ (2012), who stated that in S. obtusirostris complete yolk sac absorption takes about 25 dph.

The results of the present study of endemic species $S$. obtusirosis indicate that the number of myomeres was 55-59 in the period of 26-56 dph, which could be used for taxonomic identification of the early developmental stages of S. obtusirosis. The maximum number of myomeres on $56 \mathrm{dph}$ was 59 , which is the same as the number of vertebras. After the period of 24 to $26 \mathrm{dph}$ when S. obtusirostris started opening their mouths, 


\section{S. Nejedli et al.: Morphology of epaxial musculature and osteological development of softmouth trout}

all head bones and fins were visible. During the whole investigation period no signs of ossification in the vertebral column, fins and head bones were visible. Also, no skeletal malformations were visible which is a good indicator of optimal rearing conditions and proper diet.

\section{Acknowledgements}

This study was supported by the Ministry of Sciences, Education and Sport, Republic of Croatia (Projects: 0530010501-2107, 053-0010501-2689).

\section{References}

ARAÚJO-LIMA, C. A. R. M., E. DONALD (1988): Número de vértebras de Characiformes do rio Amazonas e seu uso na identificação de larvas do grupo. Acta Amaz. 18, 351-358.

AYALA, M. D., O. LÓPEZ-ALBORS, F. GIL, A. GARCÍA-ALCÁZAR, E. ABELLÁN, J. A. ALARCÓN, M. C. ÁLVAREZ, G. RAMÍREZ-ZARZOSA, F. MORENO (2001): Temperature effects the muscle growth in two populations (Atlantic and Mediterranen) of sea bass, Dicentrarchus labrax L. Aquaculture 202, 359-370.

BOGLIONE, C., D. PULCINI, M. SCARDI, E. PALAMARA, T. RUSSO (2014): Skeletal anomaly monitoring in rainbow trout (Oncorhynchus mykiss, Walbaum 1792) reared under different conditions. Dev. Reprod. 18, 311-319.

CAHU, C., J. ZAMBONINO, L. INFANTE, T. TAKEUCHI (2003): Nutritional components affecting skeletal development in fish larvae. Aquaculture 227, 245-258.

ÇOBAN, D., C. SUZER, H. O. KAMACI, S. SAKA, K. FIRAT (2009): Early osteological development of the fins in the hatchery-reared red porgy, Pagrus pagrus (L. 1758). J. Appl. Ichthyol. 25, 26-32.

COUGHLIN, D. J. (2002): Aerobic muscle function during steady swimming in fish. Fish Fisher. 3, 63-78.

ĆALETA, M., I. BUJ, M. MRAKOVČIĆ, P. MUSTAFIĆ, D. ZANELLA, Z. MARČIĆ, A. DUPLJIĆ, T. MIHINJAČ, I. KATAVIĆ (2015): Endemic fishes of Croatia. (Cigrofski Mustafić, M., G. Kolačko, M. Ćaleta, eds.), Croatian Environment Agency, Zagreb, pp. 85-89.

DINGERKUS, G., D. UHLER (1977): Enzyme clearing of Alcian blue stained whole small vertebrates for demonstration of cartilage. Stain Technol. 52, 229-232.

FRITZSCHE, R., G. D. JOHNSON (1980): Early osteological development of white perch and striped bass with emphasis on identification of their larvae. Trans. Am. Fish. Soc. 109, 387406.

GALLOWAY, T. F., E. KJØRSVIK, H. KRYVI (1999): Muscle growth and development in Atlantic cod larvae (Gadus morhua L.) related to different somatic growth rates. J. Exp. Biol. 202, 2111-2120. 
S. Nejedli et al.: Morphology of epaxial musculature and osteological development of softmouth trout

HASANPOUR, S. H., S. EAGDERI, B. MOJEZI AMIRI (2015): Osteological development of the vertebral column, paired, dorsal and anal fins in Rutilus caspicus, Pravdin (1927) (Teleostei: Cyprinidae). Casp. J. Env. Sci. 13, 207-219.

JOHNSTON, I. A., R. ALDERSON, C. SANDHAM, D. MITCHELL, C. SELKIRK, A. DINGWALL, D. NICKELL, R. BAKER, B. ROBERTSON, D. WHITE, J. SPRINGATE (2000): Patterns of muscle growth in early and late maturing populations of Atlantic salmon (Salmo salar L.). Aquaculture 189, 307-333.

JOHNSTON, I. A. (2001): Muscle structure and muscle growth patterns are key determinants of product quality in Atlantic salmon. In: Presented at the Cultivation of salmon II. Proceedings of the International Symposium on Cultivation of Atlantic salmon, 7-10 May, Bergen, Norway, p. 16.

KANG, C.-B., S.-H. LEE, J.-H. HWANG, K.-H. HAN (2014): Morphological development of larvae and juveniles of Acanthopagrus schlegeli. Dev. Reprod. 18, 311-319.

KOTTELAT, M., J. FREYHOF (2007): Handbook of European Freshwater Fishes. Kottelat, Crnol, Switzerland and Freyhof, Berlin, Germany.

KOUMANS, J. T. M., H. A. AKSTER (1995): Myogenic cells in development and growth of fish. Comp. Biochem. Physiol. A 110, 3-20.

KOUMONDOUROUS, G., D. G. SFAKLANAKIS, E. MAINGOT, P. DIVANACH, M. KENTOURI (2001): Osteological development of the vertebral column and of the fins in Diplodus sargus (Teleostei: Perciformes, Sparidae) Mar. Biol. 139, 853-862.

LEWIS, L. M., S. P. LALL (2006): Development of the axial skeleton and skeletal abnormalities of Atlantic halibut (Hippoglossus hippoglossus) from first feeding through metamorphosis. Aquaculture 257, 124-135.

LÓPEZ-ALBORS, O., M. D. AYALA, F. GIL, A. GARCÍA-ALCÁZAR, E. ABELLÁN, L. LATORRE, G. RAMÍREZ-ZARZOSA, M. VÁZQUEZ (2003): Early temperature effects on muscle growth dynamics and histochemical profile of muscle fibres of sea bass Dicentrarchus labrax L., during larval and juvenile stages. Aquaculture 220, 385-406.

MOWRY, R. V. (1956): Alcian blue technics for the histochemical study of acidic carbohydrates. J. Histoch. Cytoch. 4, 407-408.

MRAKOVČIĆ, M., A. BRIGIĆ, I. BUJ, M. ĆALETA, P. MUSTAFIĆ, D. ZANELLA (2006): Red Book of Freshwater Fish in Croatia. Zagreb: Ministry of Culture, State Institute for Nature Protection.

OCHOA, L. E., G. J. FERNANDEZ, L. F. JIMÉNEZ-SEGURA (2010): Development of the axial skeleton during the early ontogeny of Pimelodus sp. (Pisces: Pimelodidae), Bol. Cient. Mus. Hist. Nat. 14, 131-134.

PEARSE, A. E. G. (1968): Histochemistry, Teoretical and Aplied. J. and A. Curchill Ltd., London.

RISTOVSKA, M., B. KARAMAN, W. VERRAES, D. ADRIAENS (2006): Early development of the postcranial axial skeleton in Salmo letnica Karaman, 1924 (Teleostei: Salmonidae). BALWOIS, Conference on water observation and information system for decision support, 23-26 May, Ohrid, Macedonia, pp 1-8. 
S. Nejedli et al.: Morphology of epaxial musculature and osteological development of softmouth trout

ROGLIĆ, Z. (2012): The Development of Early Development Stages of Adriatic Trout (Salmothymus obtusirostris, Heckel, 1851). Graduate thesis, University Department of Marine Studies, University of Split, Croatia.

ROMEIS, B. (1968): Mikroskopische Technik, Oldenbourg Verlag, München-Wien, pp. 174-185.

SAKA, Ş., D. ÇOBAN, O. KAMAC, C. SÜZER, K. FIRAT (2008): Early development of cephalic skeleton in hatchery-reared Gilthead seabream, Sparus aurata. Turk. J. Fish. Aquat. Sc. 8, 341-345.

SILVESTRONE, M., L. HAMMELL (2002): Spinal deformities in farmed Atlantic salmon. Can. Vet. J. 43, 782-784.

SNOJ, A., I. BOGUT, S. SUŠNIK (2008): Evidence of a genetically distinct population of Vrljika softmouth trout Salmo obtusirostris Heckel evolved by vicariance. J. Fish Biol. 72, 1945-1959.

SPIERTS, I. L. Y. (2001): Titin isoforms and kinematics of fast swimming carp larvae (Cyprinus carpio L.) Neth. J. Zool. 51, 17-31.

TERMVIDCHAKORN, A., K. G. HORTLE (2013): A guide to larvae and juveniles of some common fish species from the Mekong River Basin. MRC Technical Paper No. 38. Mekong River Commission, Phnom Penh.

TOMLJANOVIĆ, T. (2014): Endemic softmouth trout solinka (Salmo obtusirostris salonitana). Tusculum 7, 215-224.

TREMBLAY, M. J., R. MAHON, R. O'BOYLE (1984): Vertebral numbers in larval and juvenile haddock of the scotian shelf and implications for stock discrimination. J. Northw. Atl. Fish. Sci. 5, 213-217.

VAN LEEUWEN, J. L. (1995): Review article: The action of muscles in swimming fish. J. Exp. Physiol. 80, 177-191.

VAN LEEUWEN, J. L. (1999): A mechanical analysis of myomere shape in fish. J. Exp. Biol. 202, 3405-3414.

Received: 27 September 2016

Accepted: 24 April 2017

\section{NEJEDLI, S., Z. KOZARIĆ, I. KATAVIĆ, I. ŽURA ŽAJA, I. TLAK GAJGER: Morfologija epaksijalnog mišićja i osteološki razvoj ranih stadija mekousne pastrve (Salmothymus obtusirostris, Heckel, 1851). Vet. arhiv 88, 89-100, 2018. SAŽETAK}

Istraživanja su provedena na ranim razvojnim stadijima mekousne pastrve (Salmothymus obtusirostris, Heckel, 1851). Uzorci su prikupljeni u mrijestilištu u Prološcu u blizini rijeke Vrljike, u Hrvatskoj, i to svaki drugi dan od 10. do 56. dana poslije valenja (dpv). Uzorci su fiksirani u $10 \%$-tnom formalinu i uklopljeni u parafin te izrezani u serijama na $10 \mu \mathrm{m}$ tanke rezove koji su potom obojeni hematoksilinom i eozinom, toluidinskim modrilom te alcijan plavo-specifičnom $(\mathrm{pH}=2,5)$, alcijan plavom i alcijan crvenom metodom bojenja. Broj miomera u dorzalnoj epaksijalnoj muskulaturi mekousnih pastrva povećavao se s povećanjem njihove dobi te je između 10. i 18. dpv iznosio 42, a između 50. i 56. dpv 59 miomera. Dužina tijela u razdoblju od 10. do 50. dpv povećavala se od minimalno 19,57 do maksimalno izmjerene vrijednosti od 25,80 mm. Broj kralježaka u svih istraživanih uzoraka bio je 59. Praćenjem razvoja mekousnih pastrva do stadija potpune 
S. Nejedli et al.: Morphology of epaxial musculature and osteological development of softmouth trout

apsorpcije žumančane vrećice 24. - 26. dpv, kada su počele otvarati usta, utvrđeno je da su vidljive sve kosti glave i sve peraje. U razdoblju od 26. do 56. dpv broj miomera mekousne pastrve iznosio je 55 - 59 i taj bi podatak mogao poslužiti za taksonomsku identifikaciju ranih razvojnih stadija mekousnih pastrva. Tijekom cijelog istraživanja nisu utvrđeni vidljivi znakovi osifikacije na kralješcima, kostima glave ili na perajama niti su utvrđene vidljive malformacije kostura.

Ključne riječi: mekousna pastrva; (Salmothymus obtusirostris, Heckel, 1851); rani razvojni stadiji; epaksijalna muskulatura; osteološki razvoj 